\title{
Penerapan Saluran Air Tanpa Listrik dengan Pembangunan Bendungan untuk Mendapatkan Air Bersih
}

\author{
Nurfajriah ${ }^{*}$, Santika Sari ${ }^{2}$, Noverdo Saputra ${ }^{3}$, Wahyu Maulana ${ }^{4}$, Alif Hendradi ${ }^{5}$, \\ Annisa Putriana Saputro ${ }^{6}$, Azriel Fadhillah ${ }^{7}$ (D) \\ 1,2.3,4,5,6,7 Fakultas Teknik, Universitas Pembangunan Nasional Veteran Jakarta, Jakarta, Indonesia \\ *Corresponding author: santika.sari@upnvj.ac.id
}

\begin{abstract}
Abstrak
Ketersediaan air bersih bagi masyarakat adalah salah satu jaminan bagi keberlangsungan hidup yang sehat dan sejahtera. Permasalahan yang terjadi di desa-desa adalah masyarakat masih ada yang sulit mendapatkan air bersih karena jarak sumber air yang teramat jauh. Tujuan pengabdian ini adalah pengadaan air bersih berteknologi pompa hidram (hidrolik RAM) agar bisa dirasakan oleh masyarakat. Metode pelaksanaan dilakukan 3 tahap, tahap 1 studi pengamatan permasalahan mitra, tahap 2 menawarkan solusi dan persiapan saluran air dan tahap 3 yaitu pelaksanaan program dan sosialisasi. Langkah-langkah kegiatan yang akan dilaksanakan dalam program ini adalah: (1) Sosialisasi program, (2) Persiapan peralatan dan bahan, (3) Membuat bendungan air, (4) Pelaksanaan kegiatan penyambungan pipa-pipa output dari bendungan air menuju toren penampungan akhir (5) Pendampingan, dan (6) Monitoring dan evaluasi pelaksanaan kegiatan. Berdasarkan hasil kegiatan yang telah dilakukan, dapat disimpulkan bahwa air dapat tersalurkan dengan baik sampai ke toren penampungan akhir dekat lokasi pemukiman warga dan dapat membantu warga kampung untuk mendapatkan air bersih.
\end{abstract}

Kata Kunci: Air Bersih, Pompa Saluran Air

\section{Abstract}

The availability of clean water for the community is one of the guarantees for the continuity of a healthy and prosperous life. The problem that occurs in the villages is that there are still people who find it difficult to get clean water because the water sources are very far away. The purpose of this service is the provision of clean water with hydraulic ram pump technology (hydraulic RAM) so that it can be felt by the community. The implementation method is carried out in 3 stages, stage 1 is an observational study of partner problems, stage 2 offers solutions and preparation of waterways, and stage 3 is program implementation and socialization. The activity steps that will be carried out in this program are (1) Program socialization, (2) Preparation of equipment and materials, (3) Construction of water dams, (4) Implementation of the activity of connecting the output pipes from the water dam to the final storage tower. (5) Assistance, and (6) Monitoring and evaluation of the implementation of activities. Based on the results of the activities that have been carried out, it can be concluded that the water can be channeled properly to the final storage tower near the residential area and can help the residents of village to get clean water.

Keywords: Clean Water, Water Pumps

\section{INTRODUCTION}

Kebutuhan air bersih merupakan suatu kebutuhan dasar yang sangat penting bagi kehidupan makhluk hidup karena air merupakan bagian terbesar penyusun tubuh makhluk hidup. Ketersediaan air bersih bagi masyarakat adalah salah satu jaminan bagi keberlangsungan hidup yang sehat dan sejahtera (Febriani et al., 2020; Kristianto et al., 2017; Putra \& Marsono, 2015). Air mempengaruhi berbagai aspek yang meliputi kesehatan masyarakat, ekonomi, sosial, dan peningkatan tata kehidupan masyarakat setempat. Pengadaan air bersih di Indonesia khususnya untuk skala besar hanya terpusat pada daerah perkotaan yang dikelola oleh Perusahan Air Minum (PAM) dan secara nasional jumlahnya masih belum mencukupi dan dapat dikatakan relatif kecil yakni sebesar 16,08\%. Permasalahan air bersih tersebut juga dialami oleh Kampung Cijantur, Desa Rabak, Kecamatan Rumpin, Kabupaten Bogor yang

$\begin{array}{ll}\text { History: } & \\ \text { Received } & \text { : July 10, } 2021 \\ \text { Revised } & \text { : July 12, } 2021 \\ \text { Accepted } & \text { : August 12, } 2021 \\ \text { Published } & \text { : August 25, } 2021\end{array}$


memiliki 5 Rukun Tetangga (RT) dengan masing-masing RT dihuni oleh sekitar 80 kepada keluarga. Kampung Cijantur dapat dikatakan sebagai desa yang cukup tertinggal karena banyaknya permasalahan yang dialami kampung ini, mulai dari mata pencaharian utama masyarakat yang tidak menentu, mereka hanya bertani yang tidak pasti waktu panennya. Kondisi kampung Cijantur juga sangat terbatas dan tidak didukung dengan fasilitas yg memadai. Hal ini ditandai dengan hanya terdapat satu Sekolah Dasar dengan tenaga pengajar yang minim. Selain itu, sekalipun berada di dataran tinggi kampung ini masih kesulitan mendapatkan air bersih. Sedangkan sekarang ini, keberadaan air yang masih layak untuk dikonsumsi yaitu air tanah dan mata air.

Beberapa permasalahan yang dialami Kampung Cijantur salah satunya sulitnya mendapatkan air bersih menjadi masalah yang paling dirasakan oleh masyarakat Kampung Cijantur, terutama dalam masa pandemi COVID-19 seperti sekarang ini, kebersihan menjadi hal yang sangat diutamakan. Pandemi COVID-19 yang terjadi telah mempengaruhi hampir seluruh segmen kehidupan, salah satunya yaitu kebiasaan menjaga kebersihan. Kebersihan merupakan hal utama yang harus diperhatikan di masa pandemi COVID-19 karena merupakan salah satu cara untuk mencegah paparan virus. Ketersediaan air bersih yang memadai menjadi prasyarat terwujudnya perilaku hidup bersih dan sehat (PHBS) terutama pada masa pandemiCOVID-19. Terdapat beberapa studi kasus pada penelitian sebelumnya, untuk mengatasi wilayah yang kekurangan air digunakan beberapa metode untuk penyaluran air yaitu dengan pengadaan perpipaan dengan sistem pengaliran pompa dan memanfaatkan sistem gravitasi. Sebenarnya Kampung Cijantur memiliki sumber mata air bersih, namun lokasinya sangat jauh dari pemukiman warga sehingga untuk mendapatkan air bersih warga harus berjalan cukup jauh dengan kondisi jalan yang juga tidak mudah dilalui.

Permasalahan tersebut jika dibiarkan tentu akan memberikan dampak buruk sheingga diperlukan solusi atas permasalahan tersebut. Salah satu solusi yang dapat digunakan untuk mengalirkan sumber mata air bersih yang jauh ke daerah pemukiman penduduk yaitu dengan membangun bendungan pada ketinggian sekitar 200m yang kemudian akan mengalirkan air melalui pipa sehingga dapat teralirkan ke rumah-rumah warga. Aliran air akan bergerak dari permukaan yang lebih tinggi ke permukaan yang lebih rendah. Apabila permukaan air sama, maka air berada dalam keadaan tenang atau tidak bergerak lagi. Derasnya aliran suatu air dapat diketahui berdasarkan ketinggian permukaan air antara keduanya. Prinsip kerja pompa hidraulik ram adalah melipatgandakan kekuatan pukulan air pada rumah pompa, sehingga terjadi perubahan energi kinetik menjadi tekanan dinamik yang mengakibatkan tekanan tinggi di dalam pompa (Mulyadi et al., 2017; Subroto \& Shodiqin, 2015; Supriyanto \& Irawan, 2017).

Beberapa pengabdian yang sejalan dengan pengabdian ini seperti yang dilakukan oleh (Nelson et al., 2020) menyatakan bahwa penduduk belum memiliki akses air bersih, dan masih sangat bergantung ke air sungai untuk memenuhi kebutuhan air sehari-hari sedangkan tingkat kekeruhan dan kualitas air sungai tidak memenuhi syarat air bersih sehingga solusi untuk permasalahan tersebut adalah pengembangan teknologi penyaringan air menggunakan biochar sebagai adsorben. Kemudian penelitian yang dilakukan oleh (Suyeno et al., 2014) menyatakan bahwa fukungan sumber daya memberikan pengaruh yang besar terhadap tercapai tidaknya tujuan kebijakan pelayanan air bersih wilayah perkotaan di PDAM. Tujuan pengabdian ini adalah untuk pengadaan air bersih berteknologi pompa hidram (hidrolik RAM) agar bisa dirasakan oleh masyarakat Kampung Cijantur.

\section{MATERIALS AND METHODS}

Metode pelaksanaan dilakukan 3 tahap, tahap 1 studi pengamatan permasalahan mitra, tahap 2 menawarkan solusi dan persiapan saluran air dan tahap 3 yaitu pelaksanaan program dan sosialisasi. Alur pelaksanaan dapat dilihat pada Gambar 1. 


\section{PERMASALAHAN MITRA}

Selama ini masyarakat Kampung Cijantur sulit mendapatkan air bersih, Jangkauan sumber mata air dan pemukiman warga sangat jauh, Kurangnya pengetahuan masyarakat terkait pembuatan bendungan air dan menyalurkannya.

\section{SOLUSI YANG DITAWARKAN}

Pembuatan bendungan air dengan perbedaan ketinggian 200m sehingga dapat disalurkan menggunakan pipa-pipa hingga sampai ke dalam tempat penampungan akhir yang dekat dengan lokasi pemukiman warga.

\section{PELAKSANAAN PKM DAN SOSIALISASI}

Melakukan pembuatan bendungan air dan memasang pipa-pipa untuk disalurkan dari bendungan air sampai kepada toren akhir yang berlokasi di di dekat penampungan warga. Selanjutnya memberikan sosialisasi kepada warga akan pentingnya air bersih untuk hidup sehat.

Gambar 1. Diagram Alur PKM

\section{RESULTS AND DISCUSSION}

\section{Hasil}

\section{Sosialisasi Program}

Sosialisasi Program PKM yang telah berhasil di danai oleh internal kampus kepada masyarakat. Dalam kegiatan ini kami berkumpul dengan warga untuk berkoordinasi terkait langkah selanjutnya yang perlu dilakukan untuk merealisasikan program. Pada koordinasi kali ini kami juga menyampaikan kepada warga bahwa teknologi Pompa Hidram tidak di gunakan dalam kegiatan ini, karena terkendala oleh biaya yang tidak mencukupi untuk membeli pompa. Sehingga tim berinisiatif untuk merubah metode dengan membuat bendungan air kemudian menyalurkannya dengan pipa-pipa yang dikumpulkan dalam toren akhir. Dokumentasi kegiatan koordinasi dengan warga dapat dilihat pada Gambar 2.

\section{Mempersiapkan bahan dan peralatan}

Setelah melakukan kooridnasi dengan warga maka selanjutnya kami mempersiapkan alat dana bahan yang diperlukan untuk membuat bendungan dan saluran air. Peralatan yang digunakan dapat dilihat pada Tabel 1. Setelah mempersiapkan peralatan dan bahan material yang diperlukan maka barang-barang tersebut diletakkan di titik pemasangan untuk selanjutnya dilakukan pembuatan bendungan air dan pemasangan pipa. Kendala yang terjadi dalam membawa barang ke titik lokasi adalah medan yang cukup terjal dan becek dikarenakan hujan yang turun selama beberapa hari berturut-turut. Namun setelah kondisi cuaca telah membaik maka dapat dilakukan kembali membawa peralatan dan bahan ke titik lokasi, berikut gambar kegiatan membawa alat dan bahan ke titik lokasi bendungan air. Dokumentasi kegiatan membawa alat dan bahan ke titik lokasi dapat dilihat pada Gambar 3. 
Tabel 1. Peralatan yang digunakan

\begin{tabular}{ccc}
\hline Bahan & Jumlah & Keterangan \\
\hline Drum & 1 buah & Ukuran 120 lt \\
Toren & 1 buah & Ukuran 500 lt \\
Pipa Rucika & 50 buah & Ukuran 0,5 inch \\
Pipa biasa & 180 buah & Ukuran 0,5 inch \\
Sambungan pipa L & 9 buah & Ukuran 0,5 inch \\
Sambungan pipa T & 2 buah & Ukuran 0,5 inch \\
Kran & 1 buah & \\
Stop kran & 2 buah & Ukuran 0,5 inch \\
\hline
\end{tabular}

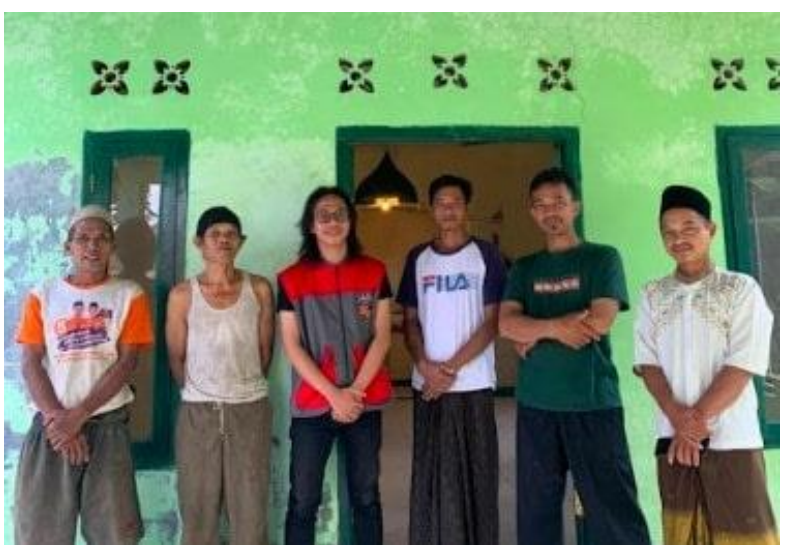

Gambar 2. Bertemu dengan Warga untuk Persiapan Kegiatan

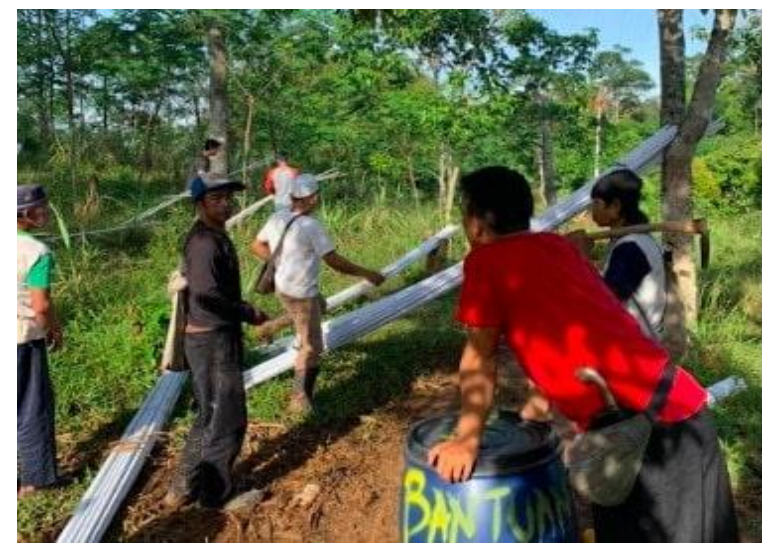

Gambar 3. Kegiatan Membawa Peralatan Dan Bahan Ke Lokasi

\section{Proses pembuatan bendungan air dan saluran air}

Pada tahapan kegiatan ini kami bersama warga saling membantu untuk membuat bendungan. Proses pengerjaan berlangsung selama 2 hari, dimana hari pertama adalah penentuan titik peletakan drum yang dipilih sebagai tempat bendungan air. Titik drum diletakkan di dekat sumber air bersih yang telah dipilih oleh warga setempat. Proses penetuan titik ini merupakan hal yang sangat penting dikarenakan pengaruh kebersihan sumber mata air dan ketinggian air menjadi kriteria dalam penentuannya. Kegiatan penentuan titik peletakan drum dapat dilihat pada Gambar 4 dan kegiatan peletakan drum sesuai titik dapat dilihat pada Gambar 5.

Setelah melakukan peletakan drum maka selanjutnya adalah memasang pipa-pipa yang digunakan untuk menyalurkan air hingga ke titik penampungan akhir yang dekat dengan pemukiman warga. Pipa dipasang sepanjang \pm 850 meter untuk sampai ke penampungan akhir. Pipa-Pipa tersebut dipasangkan pada hari kedua dan dibantu oleh warga setempat agar dapat terselesaikan tepat waktu. Kegiatan pemasangan pipa dan perapihan pipa dapat dilihat pada Gambar 6 dan Gambar 7. 


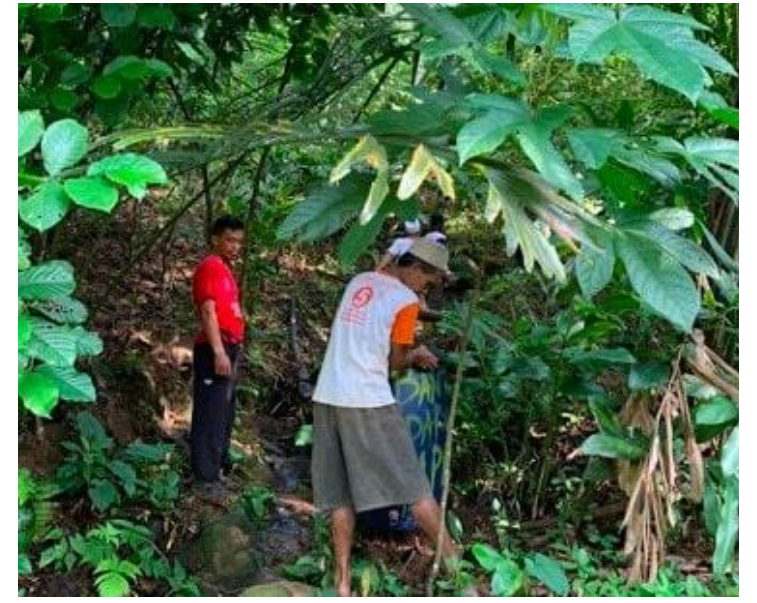

Gambar 4. Penentuan titik peletakan drum

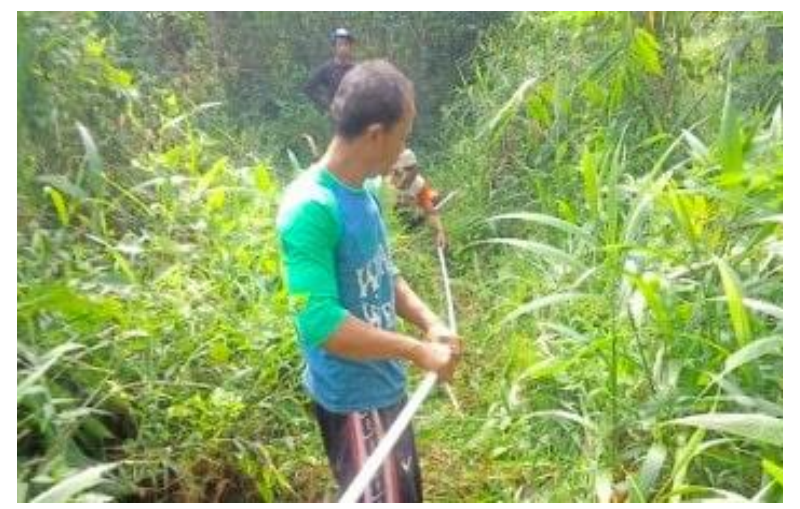

Gambar 6. Proses Pemasangan Pipa

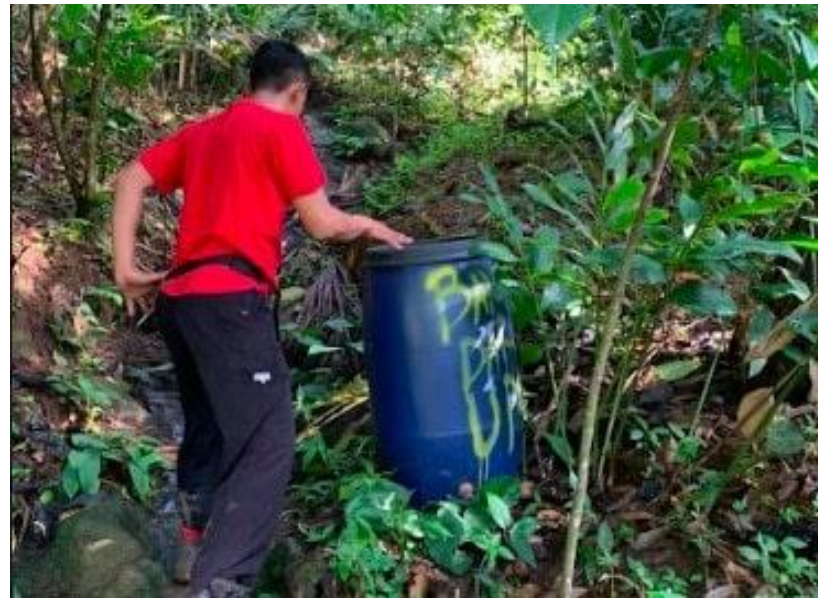

Gambar 5. Peletakkan drum sesuai titik.

Setelah melakukan pemasangan pipa dan perapihan saluran air maka dilanjutkan dengan pemasangan toren di titik penampungan akhir yang dekat dengan lokasi pemukiman warga. Selain memasang toren di lokasi yang dekat dengan rumah warga, saluran air juga disambungkan ke Musholla sehingga dapat membantu masyarakat yang ingin berwudhu. Pemasangan toren di lokasi dan pemasangan saluran air ke musholla dapat dapat dilihat pada Gambar 8 dan Gambar 9.

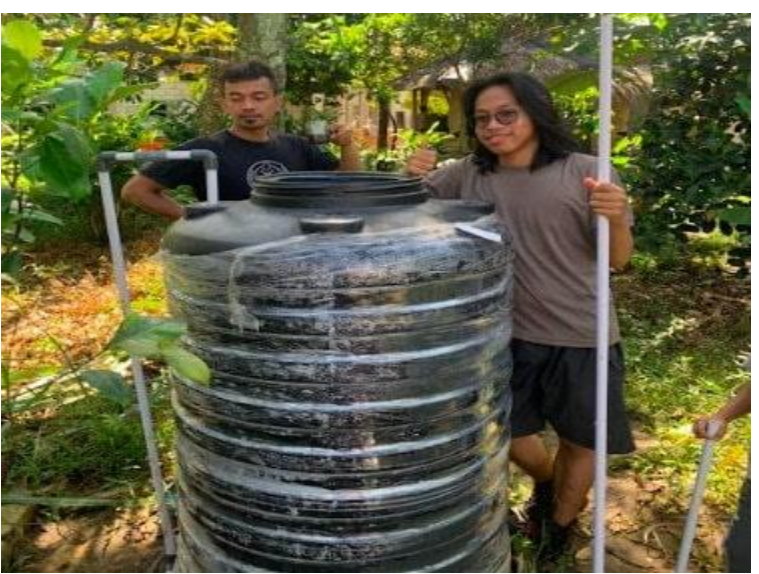

Gambar 8. Pemasangan Toren di Lokasi Akhir

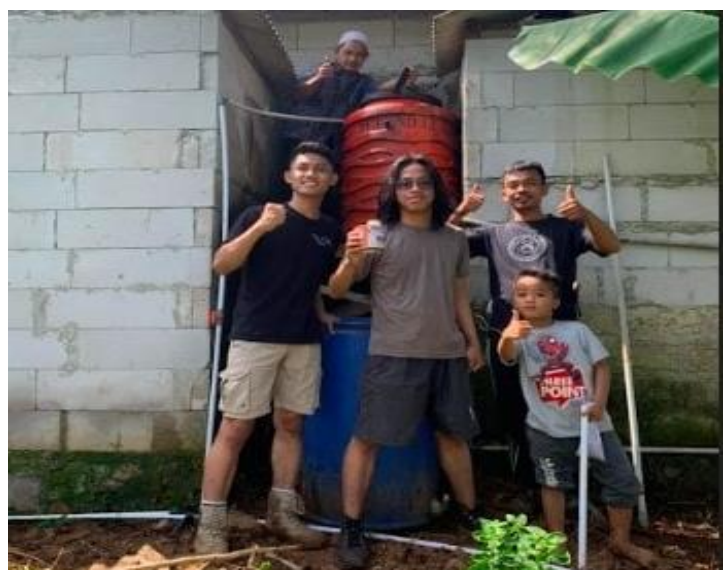

Gambar 9. Pemasangan Saluran Air ke Musholla 
Setelah menunggu kurang lebih 5 jam air sudah dapat mengalir hingga ke toren penampungan air dan juga ke musholla. Warga merasakan sekali manfaat dari lokasi titik air bersih yang dekat dengan pemukiman dan juga dapat menghemat waktu warga dalam mencari air bersih. Setelah itu dilakukan serah terima penerapan saluran air dengan teknologi pompa hidram (hidrolik RAM) tersebut kepada perwakilan masyarakat Kampung Cijantur yang disaksikan oleh para masyarakat setempat. Proses serah terima saluran air berteknologi pompa hidram (hidrolik RAM) dengan masyarakat Cijantur dapat dilihat pada Gambar 10.

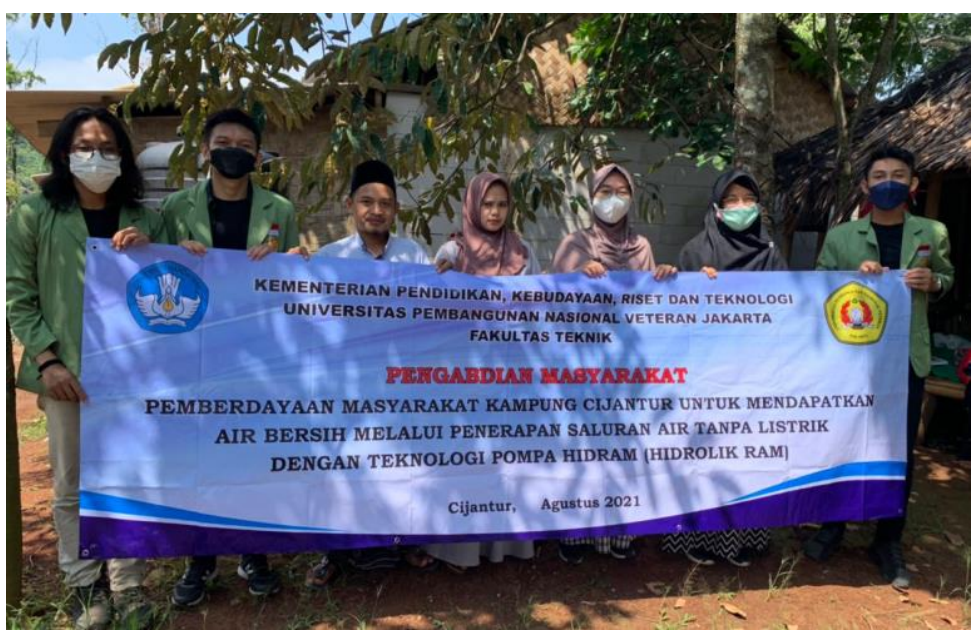

Gambar 10. Serah terima saluran air berteknologi pompa hidram (hidrolik RAM) dengan masyarakat Kampung Cijantur

Air adalah sumber kehidupan yang dibutuhkan oleh makhluk hidup di bumi, terutama manusia. Manusia membutuhkan air untuk memenuhi kebutuhan sehari-hari. bagi masyarakat yang berada jauh dari sumber air atau berada pada daerah yang lebih tinggi dari pada sumber air, dapat menggunakan peralatan mekanis untuk membantu dalam penyediaan air. Pompa adalah peralatan mekanis untuk mengubah energi mekanik dari mesin penggerak pompa menjadi energi tekan fluida yang dapat membantu memindahkan fluida ke tempat yang lebih tinggi elevasinya (Arifin et al., 2019; Harmini \& Nurhayati, 2018; Sumarjo et al., 2017). Pompa hidram adalah suatu alat untuk menaikan air dari tempat rendah ke tempat yang lebih tinggi, pompa ini tidak membutuhkan sumber energi listrik maupun bahan bakar, dan dapat bekerja terus menerus, tidak membutuhkan pelumasan, biaya pembuatan dan perawatan murah, bentuknya sederhana, dan dapat menaikkan air ke tempat rendah ke tempat yang lebih tinggi (Abdelsalam \& Gabbar, 2021; Irkhos et al., 2014; Suarda et al., 2018). Sehingga pompa ini sangat tepat untuk daerah-daerah yang jauh dari sumber listrik, karena pompa ini pemeliharaannya sangat sederhana. Mekanisme pompa hidram (Hydraulic Ram Pump) yaitu air masuk dari terjunan melalui pipa penghantar masuk kekatup limbah atau katup pembuangan dan didorong kekatup penghisap yang akan membuka akibat dorongan air dan akan masuk ke tabung kompresi.

\section{CONCLUSION}

Kesimpulan dari kegiatan PKM ini bahwa pentingnya air bersih dalam kehidupan bermasyarakat yang sudah merupakan kebutuhan pokok dalam rumah tangga. Melihat lagi dalam kondisi pandemic Covid-19 mengharuskan untuk dapat hidup sehat dan bersih, maka dengan adanya kendala yang warga rasakan mengenai kesulitan mendapatkan air bersih, kami memberikan solusi dengan keterbatasan dana yang ada. Solusi yang kami tawarkan yaitu menyalurkan air dari sumber air dan menampungnya ke titik yang dekat dengan pemukiman 
warga. Terlaksananya kegiatan PKM ini dapat memberikan manfaat secara langsung yang dirasakan warga untuk medapatkan air bersih dan secara tidak langsung mengedukasi warga untuk hidup sehat dan bersih.

\section{REFERENCES}

Abdelsalam, A. A., \& Gabbar, H. A. (2021). Energy saving and management of water pumping networks. Heliyon, 7(8), e07820. https://doi.org/10.1016/j.heliyon.2021.e07820.

Arifin, R., Malyadi, M., Kurniawan, E., \& Rosyidin, Z. U. (2019). Upaya Peningkatan Efektifitas Pengairan Sawah dengan Sistem Kontrol Pompa Air Listrik. Dinamisia: Jurnal Pengabdian Kepada Masyarakat, 3(2), 228-234. https://doi.org/10.31849/dinamisia.v3i2.3245.

Febriani, Y., Fathoni, A., Rahmi, A., \& Saleh, A. R. (2020). Peningkatan Kapasitas Desa Bangun Purba sebagai Desa Mandiri Air Bersih Berbasis Masyarakat yang Berkelanjutan. E-Dimas: Jurnal Pengabdian Kepada Masyarakat, 11(4), 499-506. https://doi.org/10.26877/e-dimas.v11i4.4634.

Harmini, H., \& Nurhayati, T. (2018). Desain Sistem Pompa Air Solar Photovoltaic (Spv) 125 Watt Di Desa Rambat, Kecamatan Geyer, Kabupaten Grobogan. Elektrika, 10(1), 10. https://doi.org/10.26623/elektrika.v10i1.1118.

Irkhos, I., Suhendra, S., \& Sukisno, S. (2014). Penerapan Pompa Hidram Metode Paralel Di Desa Pungguk Beringin Bengkulu Tengah. Dharma Raflesia Unib, 12(2), 118-128. https://doi.org/https://doi.org/10.33369/dr.v2i12.3423.

Kristianto, H., Katherine, K., Soetedjo, J. N. M., Pratiwi, F., Handriono, C. W., Guntoro, V. J., Farand, R. J., Suhendar, B. Y., \& Mulyana, Y. (2017). Penyediaan Air Bersih Masyarakat Sekitar Masjid Al-Iklas Desa Cukanggenteng Ciwidey dengan Menggunakan Penyaringan Air Sederhana. Jurnal Pengabdian Kepada Masyarakat (Indonesian Journal of Community Engagement), 3(1), 39-49. https://doi.org/10.22146/jpkm.28148.

Mulyadi, G. R., Lesmana, I. G. E., \& Hartantrie, R. C. (2017). Pengaruh Jarak Katup Limbah Dengan Katup Penghantar Terhadap Efisiensi Hidram. Jurnal Teknik Mesin, 6(4), 268272. https://doi.org/10.22441/jtm.v6i4.2099.

Nelson, N., Fahyuan, H. D., Deswardani, F., Nurhidayah, N., \& Afrianto, M. F. (2020). Pemberdayaan masyarakat dalam pengolahan air Sungai Batanghari menjadi air bersih menggunakan adsorben biochar. Riau Journal of Empowerment, 3(1), 61-68. https://doi.org/10.31258/raje.3.1.61-68.

Putra, A. P., \& Marsono, B. D. (2015). Desain Mobile Unit Instalasi Pengolahan Air Minum Untuk Kondisi Darurat Bencana Banjir. Jurnal Teknik ITS, 4(1). https://doi.org/http://dx.doi.org/10.12962/j23373539.v4i1.8852.

Suarda, M., Ghurri, A., Sucipta, M., \& Suweden, I. N. (2018). Kajian eksperimental head losses katup limbah pompa hydram. Jurnal Energi Dan Manufaktur, 10(2), 86-89. https://ojs.unud.ac.id/index.php/jem/article/view/37383.

Subroto, S., \& Shodiqin, S. (2015). Pengaruh Volume Tabung Tekan Terhadap Unjuk Kerja Pompa Hidram. Media Mesin: Majalah Teknik Mesin, 16(1). https://doi.org/10.23917/mesin.v16i2.1512.

Sumarjo, J., Arbi, A. A., \& Dirja, I. (2017). Analisis Dan Perencanaan Kebutuhan Pompa Untuk Memenuhi Kebutuhan Air Bersih Pdam Tirta Tarum Karawang Cabang Telukjambe Sepuluh Tahun Yang Akan Datang. Jurnal Teknologi, 9(2), 77-82. https://doi.org/10.24853/jurtek.9.2.77-82.

Supriyanto, A., \& Irawan, D. (2017). Pengaruh Variasi Jarak Sumbu Katup Limbah Dengan. TURBO Jurnal Teknik Mesin Universitas Muhamadiyah Metro, 6(2), 185-192. 
http://ojs.ummetro.ac.id/index.php/turbo.

Suyeno, S., Wijaya, A. F., \& Hanafi, I. (2014). Implementasi Kebijakan Pelayanan Air Bersih Wilayah PerkotaanBerbasis Kerja Sama Pemerintah dan Swasta di Kecamatan Mandau. Jurnal WACANA, 17(1), $21-34$. https://wacana.ub.ac.id/index.php/wacana/article/view/291. 